\title{
"A mass of anomalies": Land, Law, and Sovereignty in an Indian Company Town
}

\author{
MIRCEA RAIANU \\ History, University of Maryland
}

It would appear the town rose as in an Arabian Night's Dream out of airy nothing, the wild bushes wherein lurked the tiger and the jackal giving place to fiery furnaces, boilers and power-houses foundries and tall chimneys, all the creation of one single firm, illustrating Marx's famous statement that Capitalism has accomplished wonders far surpassing Egyptian pyramids, Roman aqueducs [sic] and Gothic Cathedrals.

M. D. Darookhanavala, The Indian Politeia (1949) ${ }^{1}$

Celebrated as a triumph of capitalism over both nature and history, Jamshedpur is a city of many firsts. It is the first company town to be established and run by an Indian firm, the Tata Iron and Steel Company (TISCO), as well as the site of the first successful experiment with heavy industrial production in the interior of the subcontinent. Located at the confluence of the Kharkai and Subarnarekha Rivers, approximately 250 miles west of Calcutta on the Bengal-Nagpur Railway, Jamshedpur was ideally situated to take advantage of the main natural resources necessary for steelmaking (coal, iron ore, limestone, and water), and of a steady supply of local labor drawn from the adivasi (tribal)

Acknowledgments: My foremost thanks go to the anonymous CSSH reviewers, whose detailed and incisive readings of the manuscript challenged and clarified my arguments. Maya Jasanoff read several early drafts and made each better than the last. John and Jean Comaroff provided key insights that unlocked the broader relevance of this story. Previous versions of the article were presented at the Modern South Asia Workshop at Yale in April 2015 and the Shades of Sovereignty Workshop at Stanford in May 2016. I am grateful to the organizers and participants, especially Rohit De, Karuna Mantena, Eric Beverley, and Thomas Blom Hansen, for their comments and suggestions. Research in India was supported by the Fulbright-Nehru and Frederick Sheldon Fellowships in 2013-2014. Finally, I thank the staff of the numerous archives I consulted, and everyone who agreed to speak with me in Mumbai, Delhi, Jamshedpur, and Ranchi. All errors and omissions are my own.

1 M. D. Darookhanavala, The Indian Politeia (Bombay: Lakhani Book Depot, 1949), 42-43. This exuberant description of Jamshedpur is taken from a long manifesto defending the achievements of Indian capitalism during the colonial period, written shortly after independence by a former employee of the Tata firm. 
population. Since its foundation in 1909, Jamshedpur has continued to grow. Today it is one of the oldest and largest extant company towns in the world, with a population exceeding one million. Moreover, the Jamshedpur model of private urban governance has proven exceptionally resilient up to the present, neither pure capitalist enclave nor regionally integrated municipality. ${ }^{2}$ It typifies a flexible, heterogeneous form of corporate sovereignty, dependent on the state in some respects but fiercely resistant to it in others.

Company towns have long served as "outposts introducing industrial capitalism into previously unexploited territory." ${ }^{\prime 3}$ In the Indian context, Jamshedpur was a radically new type of urban settlement, marking a departure from the paradigmatic spaces of colonial urbanism, such as the military cantonment and the hill station. ${ }^{4}$ Embodying a vision of industrial modernity as a break in space (a factory and planned township out of the jungle) and time (industrial production as a developmental advance in a largely agrarian society), Jamshedpur prefigured the wave of planned "new towns" in the mid-twentieth century, described by Rosemary Wakeman as quintessentially utopian and pedagogical "fantasy acts." ${ }^{, 5}$ But it was markedly different from the later state-run steel cities of Bhilai, Rourkela, and Durgapur, the "grounded and inhabited 'dreamworlds" of the postcolonial Indian nation," which were designed to at least partially absorb rural and tribal populations and transform them into productive citizens. ${ }^{6}$ By contrast, Jamshedpur had been "conceived as an entirely original space that should exclude them." Here "industrial modernity would wholly supplant the indigenous culture," replacing "subsistence-farming and huntergathering with a diverse migrant population."7

Jamshedpur's autarkic and exclusionary nature exemplified a wider tendency by Indian industrialists to secure footholds in upcountry regions by establishing firmly bounded enclaves. ${ }^{8}$ The Tatas' own Empress Mills at

2 Blair Kling, "Paternalism in Indian Labor: The Tata Iron and Steel Company of Jamshedpur," International Labor and Working-Class History 53 (Spring 1998): 69-87. In 2009, Jamshedpur won the UN Global Compact City Award, "a remarkable success story in the face of the decline of company towns elsewhere in the world." Amita Sinha and Jatinder Singh, "Jamshedpur: Planning an Ideal Steel City in India," Journal of Planning History 10, 4: 263-81.

${ }^{3}$ Margaret Crawford, Building the Workingman's Paradise: The Design of American Company Towns (London: Verso, 1995), 6-7.

${ }^{4}$ Sinha and Singh, "Planning an Ideal Steel City in India," 264. See also Anthony King, Colonial Urban Development: Culture, Social Power, and Environment (London: Routledge \& Kegan Paul, 1976).

${ }^{5}$ Rosemary Wakeman, Practicing Utopia: An Intellectual History of the New Town Movement (Chicago: University of Chicago Press, 2016), 4.

${ }^{6}$ Srirupa Roy, Beyond Belief: India and the Politics of Postcolonial Nationalism (Durham: Duke University Press, 2007), 135.

7 Andrew Sanchez and Christian Strümpell, "Sons of Soil, Sons of Steel: Autochthony, Descent and the Class Concept in Industrial India," Modern Asian Studies 48, 5 (2014): 1276-301.

8 A.D.D. Gordon, Businessmen and Politics: Rising Nationalism and a Modernising Economy in Bombay, 1918-1933, Australian National University Monographs on South Asia (Delhi: Manohar, 1978), 111-12. 
Nagpur, opened in 1877, was an early instance of this tendency, even as cotton and jute mills remained heavily concentrated in the colonial Presidency capitals of Bombay and Calcutta. Jamshedpur's emergence thus marked a further turning point in the long-term spatial shift from the coastal world of maritime export trade, dominated by British expatriate firms, to the exploitation of mineral resources in the interior by Indian capital in accordance with the nationalist rhetoric of swadeshi (self-sufficiency). As a powerful discursive trope animating the colonial civilizing mission, the "interior" had come to be envisioned in strictly economic terms, as a "repository of hidden wealth and resources that needed to be exploited." Vast spaces deemed jungli (wild) were to be "opened up" through roads, railways, and steamships. ${ }^{9}$ But at the same time, colonial administrators sought to render the landscape "productive and secure for the formation of stable village communities" by encouraging forest clearing and cultivation. $^{10}$

The transformation of the social, political, and ecological landscapes of the interior rested, first and foremost, on the workings of the law. Land acquisition for railway and port development companies under the "guarantee system" relied on legal mechanisms of compulsory dispossession. ${ }^{11}$ The passage of the far-reaching Land Acquisition Act (1894) allowed for the transfer of land to private companies provided they fulfilled a "public purpose," which usually meant infrastructural improvements. While the distinction between public and private was murky and ill defined, the colonial state remained paramount as the "supreme landlord." 12 If private companies like TISCO began to function as surrogate states by administering large tracts of land under the "public purpose" clause, this supremacy risked being undermined. Colonial officials realized only too late that Indian capitalists had secured control over valuable mineral resources at a nominal cost by exploiting ambiguities in the law and by playing multiple sovereignties against each other. Nationalist advocates of centralized economic planning also bemoaned "the confusion created by the myriads of political units ... perhaps without any parallel in the world," particularly the interspersion of indirectly ruled princely

\footnotetext{
9 Nitin Sinha, Communication and Colonialism in Eastern India: Bihar, 1760s-1880s (London: Anthem Press, 2012), xvii-xxviii.

${ }^{10}$ K. Sivaramakrishnan, Modern Forests: Statemaking and Environmental Change in Colonial Eastern India (Stanford: Stanford University Press, 1999), 35-37.

11 Beginning in the $1850 \mathrm{~s}$, railroads were constructed by private British companies backed by the colonial state, which absorbed land costs and guaranteed a 5 percent return on capital regardless of their profitability - a model of "private enterprise at public risk." Ian J. Kerr, Engines of Change: The Railroads that Made India (London: Praeger, 2007), 19-26.

12 Manu Goswami, Producing India: From Colonial Economy to National Space (Chicago: University of Chicago Press, 2004), 52-55. For a summary account of the development of land acquisition law in the late nineteenth century, see Eesvan Krishnan, "Private Speculations and the Public Interest: N. C. Kelkar's Land Acquisition Bill,” Socio-Legal Review 8, 2 (2012): 78-105.
} 
states and British territory. ${ }^{13}$ Great fortunes were made in the welter of this "confusion" of sovereignty.

The Tatas' pioneering venture, I argue, generated two seemingly contradictory yet mutually constitutive trends: the legal designation of Indian private capital (rather than British expatriate capital) as fulfilling a "public purpose," and the corresponding involvement of the state in resource capture for the purpose of industrialization (rather than agrarian rent extraction). The rich archive of legal disputes around land acquisition for Jamshedpur reveals how TISCO itself became a quasi-sovereign power in eastern India, simultaneously acting as employer, landlord, and municipal government. Neither the colonial state nor its postcolonial successor was ever able to undo this anomalous arrangement.

The persistence of multiple, fragmented, and layered sovereignties over the longue durée of South Asian history has attracted significant attention, but its implications for political economy have been underemphasized. ${ }^{14}$ At the height of the British Raj, when the Tatas built Jamshedpur, the characteristically early modern "hybrid and composite" sovereignty of the East India Company had ostensibly been rendered obsolete by the ascendancy of territorial states, both imperial and national. ${ }^{15}$ As Manu Goswami has shown, a new colonial "state space" emerged after the end of Company rule in 1858 through a range of institutions and practices, including transportation and irrigation infrastructure, state-issued paper currency, reformed hundis (bills of exchange), a single annual state budget, and the standardization of accounting procedures. Railways and other large public works reoriented earlier networks of inland trade, producing a "new uneven economic geography."16 The colonial state's territorializing project, linked to imperial markets, rearranged the spatial scales of the local, regional, and national into a "dynamic hierarchy."17

Economic unevenness accompanied the proliferation of legal anomalies, including semi-autonomous princely states and directly administered tribal areas, as sovereignty came to be envisioned as "divisible" by colonial jurists

\footnotetext{
13 Tulsi Ram Sharma, The Location of Industries in India (Bombay: Hind Kitabs Limited, 1946), $3-4$.

14 On the concept of "layered and shared sovereignty" in recent South Asian historiography, see Sugata Bose, A Hundred Horizons: The Indian Ocean in the Age of Global Empire (Cambridge: Harvard University Press, 2006), 25. The most fruitful area of research in which this concept has been debated has been the study of princely states. See, for example, Mridu Rai, Hindu Rulers, Muslim Subjects: Islam, Rights, and the History of Kashmir (Princeton: Princeton University Press, 2004), 104-11; and Eric Beverley, Hyderabad, British India, and the World: Muslim Networks and Minor Sovereignty, c. 1850-1950 (Cambridge: Cambridge University Press, 2015), 24-30.

15 Philip J. Stern, The Company-State: Corporate Sovereignty and the Early Modern Foundations of the British Empire in India (New York: Oxford University Press, 2011), 6-14, 208.

16 Goswami, Producing India, 7-19, 59.

17 Ravi Ahuja, Pathways of Empire: Circulation, Public Works and Social Space in Colonial Orissa, c. 1780-1914 (New Delhi: Orient Blackswan, 2009), 36-37.
} 
from Henry Maine onward. ${ }^{18}$ The parallel revival of chartered company imperialism and the extension of indirect rule in the Scramble for Africa suggests that, far from being "a great era of state-building and territorial consolidation," the late nineteenth century ushered in a more transactional, if not outright commodified, notion of sovereignty. Titles to land and the mineral riches that lay underneath, from coal to diamonds, were freely bought and sold by private companies, with European states initially playing an enabling role. ${ }^{19}$ Yet the multitude of treaties and contracts that secured such titles, in Africa and India alike, made little distinction between control over land and sovereignty over territory, leaving the way open for states to (re)assert their authority over "rogue" or "nomadic" forms of capital. ${ }^{20}$

At the broadest level, Joshua Barkan has theorized this phenomenon as "a kind of doubling, in which the fate of state sovereignty and corporate power are conjoined and also in conflict." States create corporations through "legally authorized suspensions, privileges, and immunities from law," for the purpose of governing territory, property, and life. Corporate charters, by giving rise to a distinct juridical personality, in turn threaten the unitary sovereignty of the state. ${ }^{21}$ But from a comparative historical perspective, the statecapital relationship has been "doubled" differently across time and space, calling attention to the specific legal and political contexts in which it takes shape. In colonial India, the "public purpose" clause of the Land Acquisition Act was far narrower in scope and intent than the corporate charter or concession, even as it unexpectedly came to mirror its functions. ${ }^{22}$ TISCO exercised near-absolute control in Jamshedpur not by devolution or delegation but as a contingent effect of competing loci of sovereignty and the absence of an overarching legal framework capable of adjudicating between them. Early on, Tata seized the weapons of colonial "lawfare," deploying them against the weak

\footnotetext{
18 Lauren Benton, A Search for Sovereignty: Law and Geography in European Empires, 1400 1900 (Cambridge: Cambridge University Press, 2010), 240-45; Sudipta Sen, "Unfinished Conquest: Residual Sovereignty and the Legal Foundations of the British Empire in India," Law, Culture and the Humanities 9, 2 (June 2013): 227-42.

19 Steven Press, Rogue Empires: Contracts and Conmen in Europe's Scramble for Africa (Cambridge: Harvard University Press, 2017), 76-78.

${ }^{20}$ Bodhisattva Kar, "Nomadic Capital and Speculative Tribes: A Culture of Contracts in the Northeastern Frontier of British India," Indian Economic and Social History Review 53, 1 (2016): 55-61. See also Press, Rogue Empires, 105.

21 Joshua Barkan, Corporate Sovereignty: Law and Government under Capitalism (Minneapolis: University of Minnesota Press, 2013), 76-78.

22 In the Sandys case (1685), the Court of the King's Bench drew a clear distinction between illicit monopolies by private interests and "licit exclusive privileges" serving the public good. The prospect of "lawless trade" in distant places justified the grant of sovereign powers to private corporate entities like the East India Company, an argument, as we will see, that resurfaced in the application of the Land Acquisition Act within the territorial boundaries of British India. Stern, Company-State, 48-57.
} 
while also turning them against the state. ${ }^{23}$ The company's sovereign prerogatives were never codified, but rather continually reproduced as exception and anomaly.

\section{SPACE AND SOVEREIGNTY IN EASTERN INDIA}

How did the Tatas come to settle on a location for their steel plant? Around the year 1900, founder Jamsetji Tata sent his son Dorabji and his nephew Shapurji Saklatvala across the length and breadth of India to secure prospecting licenses for iron ore, coal, copper, and manganese. They found themselves in the midst of a speculative frenzy, reporting back to Bombay that "everybody is mad with some mining project or another." But wherever valuable mineral resources were discovered, British firms were quick to stake their ground. For example, despite the friendly overtures of the Acting Financial Secretary to the Nizam of Hyderabad, who was "most favourably inclined towards us," the Tatas lost a copper prospecting license in the state to a British concern, Parry \& $\mathrm{Co}^{24}$ Winning the race for raw materials thus required collaboration with princely rulers and local intermediaries in order to compete with entrenched British interests.

With preliminary investigations in southern and central India yielding little result, the Tatas concentrated on a wide swath of land stretching from the plains of Bihar and western Bengal to the forests and hills of present-day Jharkhand and Odisha. During the early years of East India Company rule, this region was perceived as a wild frontier impervious to military conquest and pacification, a "zone of anomaly" where policing, land settlement, and revenue collection were delegated to powerful zamindars (landlords) and other intermediaries. In eastern India, an exceptionally dense "political society" forced the Tatas to work through entrenched power structures and indeterminate legal regimes. ${ }^{25}$ One key ally was the ruler of Mayurbhanj, the largest and highest ranked of the Orissa Tributary States. ${ }^{26}$ In 1904, the geologist P. N. Bose, then in the employ of the Maharaja, brought the extraordinarily rich iron ore deposits in the Gurumahisani District to the attention of

23 John L. Comaroff, "Colonialism, Culture, and the Law: A Foreword,” Law \& Social Inquiry 26, 2 (Apr. 2001): 305-14.

24 Tata Central Archives, Pune (hereafter TCA), FP-36, D. J. Tata to J. N. Tata, 25 Sept. 1902; Shapurji Saklatvala to J. N. Tata, 6 Oct. 1902, "Report of Mr. Shapurji's second visit to Hyderabad," 10 Oct. 1902.

25 Sivaramakrishnan, Modern Forests, 20-21, 35-37. In this context, "political society" is defined as "the local structures of government and those aspects of civil society that have extra-local political reach," for example, "headmanship, police and judicial roles of landlords, and labour contractors."

26 The princes of Orissa had eagerly seized upon the commercialization of the dormant natural resources of their kingdoms, encouraged by the colonial state. Ahuja, Pathways of Empire, 273. 
the Tatas. ${ }^{27}$ To work these deposits, an initial site for the plant was selected at Sini junction, 170 miles inland from Calcutta on the Bengal-Nagpur Railway, within the borders of the Seraikela princely state. ${ }^{28}$ Company histories narrate this series of decisions as stages in a teleological process of finding at the "right" location, driven by courageous and brilliant risk-taking. ${ }^{29}$ Even the most critical accounts begrudgingly praise Jamsetji Tata and his associates for their "entrepreneurial ability in Schumpeterian terms" in selecting a site. ${ }^{30}$ In fact, their choices were heavily constrained by resource geographies and multiple state spaces (princely and British).

Colonial officials quickly grew concerned that the new steel company would evade their control at Sini, and the potential benefits it could reap from the industry would be reduced. The local Deputy Commissioner tried to persuade the Tatas to build exclusively in British territory, because the Sini site would be "out of the direct control of British officers" and "Native States are likely to be obstructive \& troublesome in various ways." The Tatas' response was to play one power against the other: "There are two alternatives open to us:-(1) To shift the site as they advise, or (2) to obtain an option from the Raja of Seraikela fixing definite price for the land to be occupied by the Works ... it should be put before him that in case he wouldn't give us reasonable terms and a period of option, we would not establish the Works in his Territory but go over to British land." 31 But if the company bound itself to building in the Raja of Seraikela's domain, it would be giving up the possibility of using the Land Acquisition Act: "We might be thus placing ourselves at his mercy. The British Government could not help us much; there will be no land Acquisition Act to put into force; and the Raja may insist on his own price being paid." 32 Taking recourse to colonial law, whatever complications it might create in the long run, promised more security and certainty than striking an ad hoc deal with the Raja.

In 1909, the final site of the future Jamshedpur, lying well within British territory near the village of Sakchi, was chosen due not only to more a favorable resource distribution and lower transport costs (as is commonly assumed), but

\footnotetext{
27 On Bose's conflicted identity as a "colonial nationalist geologist," critiquing modern industrialization while simultaneously supporting the Tatas' efforts, see Pratik Chakrabarti, Western Science in Modern India: Metropolitan Methods, Colonial Practices (Delhi: Permanent Black, 2004), 262-63.

28 TCA, FP-41A, B. J. Padshah to D. J. Tata, 11 Nov. 1904; B. J. Padshah to R. D. Tata, 17 Feb. 1905 .

29 See, inter alia, R. M. Lala, The Romance of Tata Steel (New Delhi: Penguin, 2007); and Rudrangshu Mukherjee, A Century of Trust: The Story of Tata Steel (New Delhi: Penguin, 2008).

30 Satya Brata Datta, Capital Accumulation and Workers' Struggle in Indian Industrialisation: The Case of the Tata Iron and Steel Company, 1910-1970 (Stockholm: Almqvist \& Wiksell International, 1986), 6, 21.

31 TCA, FP, B. J. Padshah Correspondence, Padshah to R. D. Tata, 22-23 Dec. 1905.

32 TCA, FP-220, Tata Sons to R. D. Tata, 21 Dec. 1905.
} 
also to avoid potential resistance from the adivasi inhabitants. At the previous site, the Deputy Commissioner had proven "inflexible in the matter of the rights of the Kols, and is averse to dispossessing 700 families whose rights over the lands he considers to be of a peculiar nature." 33 In the wake of several adivasi uprisings against the Raj throughout the nineteenth century, culminating in the Birsa Munda's millenarian revolt of 1899 , colonial officials had cast themselves as protectors of customary rights. ${ }^{34}$

The company's decision to shift location to British territory raised an immediate legal complication due to the passage of a landmark piece of protective legislation, the Chota Nagpur Tenancy Act (1908). The Permanent Settlement of 1793 had been extended westward from Bengal to the Chotanagpur Plateau, which transformed the prevailing khuntkatti system of joint ownership of common land under family lineages. Over time, village headmen and petty tribal rajas were gradually Hinduized, eventually becoming zamindars and proprietors of the soil. Throughout the late nineteenth century, the colonial state introduced a series of piecemeal legislative measures for the benefit of tenants, alarmed at the degradation of customary joint tenures through land sales to moneylenders. The C.N.T. Act "consolidated and suspended all previous agrarian legislation for the province," with the status of the village headman coming under the protection of the law for the first time. ${ }^{35}$ The cumulative effect of the new legislation was to increase the power and discretion of the colonial revenue officer. ${ }^{36}$ But this was more than a localized display of administrative exigency. As Faisal Chaudhry has argued, the extension of tenancy and occupancy rights in the wake of the Bengal Rent Act of 1859 widened the scope of "what could be recognized as a legal entitlement well beyond property in the land's rent alone." 37 Prohibiting land transfers among certain classes or groups, as in the case of the Chotanagpur adivasis, formed part of a distinct strand in colonial legal thought in growing tension with the concurrent expansion of eminent domain powers.

Since the C.N.T. Act expressly prohibited the alienation of tribal lands, there is a widespread belief in Jharkhand today that the Tatas somehow

33 Tata Steel Archives, Jamshedpur (hereafter TSA), Land Acquisition File No. 2 (1907), Tata Sons, Agents, to H. J. McIntosh, Commissioner of Chota Nagpur, 23 Dec. 1907. See also Y. B. Vishwakarma, Industrialization and Tribal Ecology: Jamshedpur and Its Environs (Jaipur: Rawat Publications, 1991), 37-38.

34 Vinita Damodaran, "Indigenous Agency: Customary Rights and Tribal Protection in Eastern India, 1830-1930," History Workshop Journal 76 (Aug. 2013): 85-110.

35 Detlef Schwerin, "The Control of Land and Labour in Chota Nagpur, 1858-1908," in Dietmar Rothermund and D. C. Wadhwa, eds., Zamindars, Mines and Peasants: Studies in the History of an Indian Coalfield and Its Rural Hinterland (Delhi: Manohar, 1978), 36-38, 61-64.

36 Dietmar Rothermund, "Tenancy Legislation for Chota Nagpur: The Emphasis on Executive Protection," in Dietmar Rothermund and D. C. Wadhwa, eds., Zamindars, Mines and Peasants (Delhi: Manohar, 1978), 78-80.

37 Faisal Chaudhry, "A Rule of Proprietary Right for British India: From Revenue Settlement to Tenant Right in the Age of Classical Legal Thought," Modern Asian Studies 50, 1 (2016): 345-84. 
managed to delay its implementation in order to successfully carry out their acquisitions. ${ }^{38}$ Existing archival sources do not provide any clear evidence of such an arrangement. If they indeed happened, discussions would have been informal and not likely to leave a paper trail. TISCO's Resident Engineer, W. O. Renkin, did warn the Board "that the new Chota Nagpur Tenancy Act will make considerable trouble unless land acquired is declared as being exempt from it; this is purely my opinion and is offered as a suggestion only." At the top of the first page of this letter we find a barely legible scribble in pencil calling for "quick action" on the matter, and requesting details of the requirements of the C.N.T. Act. ${ }^{39}$ It can be surmised that the mere presence of the law cast a long shadow on the acquisition process, which relied on a dual strategy of appealing to the state for the use of the Land Acquisition Act in certain areas, and performing the function of zamindar in others. The Tatas inserted themselves into the complex and rapidly changing agrarian structure in Chotanagpur as a powerful intermediary, thus resolving the dilemma of how to negotiate between multiple sovereign powers that had plagued them at Sini. The solution was for the company itself to assume a concrete territorial form of sovereignty.

To understand how this solution worked in practice, and why it became possible, the wider mining landscape in the region must be considered. The most powerful agent in the local economy was the zamindar, who acted as both landlord and contractor, with the "command of village labor" deriving from his ownership of surface rights. The zamindars' income was enhanced through a wide variety of bribes and commissions, all of which were "forms of salami, a gesture which combined obeisance with extortion." In most cases, subsoil rights exploited through salami and royalties proved more profitable than the land. ${ }^{40}$ Mining companies, including the Tatas, "inserted themselves into this structure at the intermediate level of tenure-holders," and "the new extractive industry blended with the prevailing agrarian system as a kind of subsoil agriculture." 41 However, this "blending" did not occur smoothly. Frequent disputes over rights and royalties could rarely be adjudicated by existing legislation. Companies sought to systematize land tenure regimes by expropriating rival claimants, while simultaneously profiting from the internal contradictions of the law to consolidate their hold on valuable properties.

\footnotetext{
38 This view was expressed to me in a series of interviews conducted with social activists in Jamshedpur and Ranchi in April 2014.

39 TSA, Land Acquisition File No. 4 (1908, Part II), W. O. Renkin to The Tata Iron \& Steel Co., Bombay, 7 Sept. 1908.

40 Dilip Simeon, "The Currency of Sentiment: An Essay on Informal Accumulation in Colonial India," in Emmanuel Kreike and William Chester Jordan, eds., Corrupt Histories (Studies in Comparative History) (Rochester: University of Rochester Press, 2006), 407-8.

41 Dietmar Rothermund, "The Coalfield-An Enclave in a Backward Region," in Dietmar Rothermund and D. C. Wadhwa, eds., Zamindars, Mines and Peasants: Studies in the History of an Indian Coalfield and Its Rural Hinterland (Delhi: Manohar, 1978), 2-12, 18.
} 
Concessions for mineral resources were exceedingly generous, especially in princely territories. For example, in the prospecting license for iron ore drawn up in 1905, the ruler of Mayurbhanj charged the Tatas a surface rent of Rs. 100/- per annum and a royalty rate of 1 anna per ton. The neighboring state of Keonjhar, meanwhile, levied a rent of only Rs. 5/- per annum and a royalty of $1 / 2$ anna per ton. Though colonial officials found these rates to be "unduly low," they "did not consider it advisable to insist on a strict adherence to the Mining Rules prescribed for British India." Since Keonjhar was "more inaccessible than Moharbhanj [sic] and much less developed," it was "a great consideration that any respectable firm should be induced to prospect the state at all." ${ }^{42}$ Such flexible agreements allowed the colonial state to promote the infrastructural development of remote areas by proxy. Rulers proposed a quid pro quo between their states and the company, offering prospecting licenses in exchange for the promise of extending railway connections. As the diwan (minister) of Kawardha State explained, "I live in the remote corner of India which is [an] out of the way place and it is not possible for me to put the Ore into the market." The Tatas' help in linking up the Bengal-Nagpur Railway with his state would also "conduce to the well-being of the aborigines and poor people ... quite regardless of the personal gains."

At times, local authorities were willing to devolve administrative power almost completely to the mining companies. In January 1910, TISCO's representative at Balaghat in the Central Provinces informed the Director-in-Charge, B. J. Padshah, "The C.P. Govt. has given mine managers certain magisterial powers in cases where the situation of the mine has been away from any civilizing centre or among aboriginal races," which gave "the mining man a status among such people which has been the means of helping him with his work." Padshah was told to approach the Political Agent of the Orissa Feudatory States with a view to pursuing the same arrangement at the Tatas' iron mines in Mayurbhanj. ${ }^{44}$ Once a company had gained a foothold in this manner, it was nearly impossible to dislodge. By 1912, the Tatas had still not worked their iron ore concession at Dalli-Rajhara in the Central Provinces, nor had they given it up. An exasperated District Engineer surveying the area could only exclaim, "Will the Government of India allow her mineral resources

\footnotetext{
42 National Archives of India, New Delhi (hereafter NAI), Foreign Department, Internal Branch, B Proceedings, No. 298 (Sept. 1908), F. W. Duke, Chief Secretary to the Government of Bengal, to S. H. Butler, Secretary to the Government of India, Foreign Department, 7 Sept. 1908.

${ }^{43}$ TSA, File No. 602(i), Pandit Bhaiya Lal Pyasi, Diwan, Kawardha State, C.P., to The General Manager, The Tata Iron \& Steel Co., 1 Feb. 1917. In practice, new commercial opportunities accelerated the social and economic stratification between "affluent landed elements" and adivasi subjects, all the while legitimizing the power of the ruling dynasty. See Biswamoy Pati, "The Order of Legitimacy: Princely Orissa, 1850-1947," in Waltraud Ernst and Biswamoy Pati, eds., India's Princely States: People, Princes and Colonialism (Abingdon: Routledge, 2007), 89.

44 TSA, File No. 93(ii), H. C. McNeill to B. J. Padshah, 17 Jan. 1910.
} 
to be treated thus?" 45 Colonial officials began to recognize that they were negotiating from a position of weakness.

\section{LAND ACQUISITION AND THE LAW}

The initial area acquired by the Tatas near the village of Sakchi under section 41 of the Land Acquisition Act was 3,564 acres at a rate of Rs. 13 per acre, with a total compensation amount of Rs. 12,000/- paid to the expropriated raiyats (cultivators). Because the area appeared to officials "prima facie excessive," its conveyance was to be "a conditional and not an absolute transfer." The land would be put up for resale if the company failed to construct or maintain the specified works in time. ${ }^{46}$ The company's response to these legally "unprecedented" restrictions was to emphasize the "public purpose" of the steel works: "Having satisfied themselves of the desirable character of the undertaking to establish this industry ... we submit the Government are not compelled by any provision of Section 41 to make the acquisition of land for the undertaking less permanent or less absolute than if the Government were acquiring the land for themselves."47 According to Tata lawyers, colonial officials felt "oppressed by the consideration that this case is an exceptional one as it deals with a large tract of country and it is sure to be quoted as a precedent hereafter so they wish to provide for possible rights which after all may not really exist." 48 The company declared itself willing to offer alternative land for the displaced, but no explicit provisions were inserted into the agreement. There were several protests and complaints to the District Commissioner, which resulted in an undisclosed amount of crop compensation payments. However, resistance was minimized by deliberately skirting the more populated villages and directly acquiring mostly jungle and waste lands. ${ }^{49}$

Beyond the acquired area, the Tatas also held twenty-one villages on lease from the Dhalbhum zamindari estate, managed at the time by a third-party syndicate due to a succession dispute pending in the courts. Securing this lease lent an exceptional degree of flexibility to the acquisition process and laid the groundwork for future expansion: "although we are not getting these lands in the actual acquired land yet they will be within the leased lands and can be

45 TCA, T53-DES-T34-MINUTES-1-082-83, H. P. Lemesuner [sic], District Engineer, to Mr. Darlington, Bengal-Nagpur Railway, 2 Feb. 1912.

46 TSA, Land Acquisition File No. 3 (1908, pt. I), F. H. Eggar, Solicitor to Govt., to Commissioner of Chota Nagpur, 21 Apr. 1908.

47 TSA, Land Acquisition File No. 3 (1908, pt. I), Morgan \& Co. to F. H. Eggar, Solicitor to Govt., 26 June 1908.

${ }^{48}$ TSA, Land Acquisition File No. 5 (1908, pt. III), Morgan \& Co. to Messrs. Tata Sons \& Co., 14 July 1908.

49 TSA, Land Acquisition File No. 3 (1908, pt. I), The Tata Iron and Steel Co. Ltd. to The Chief Secretary to the Government of Bengal, Revenue Department, 3 Feb. 1908; Land Acquisition File No. 4 (1908, pt. II), W. O. Renkin to Tata Iron \& Steel Co., 30 Oct. 1908; Maya Dutta, Jamshedpur: The Growth of the City and Its Regions (Calcutta: Asiatic Society, 1977), 6-7. 
later acquired through Government much easier than now." 50 The terms of the lease provided for the "complete transfer of all rights in the lands," with the exception of profits made from the sale of wood (one of the zamindar's main sources of income). Otherwise the company was assured that "there is a distinct understanding that the Rs. 30,000/- [the cost of the lease] is to enable you to make any profit from any source whatever, the Syndicate indemnifying you against all possible claims by the Rajah." 51 The company was, however, reminded by the Deputy Commissioner that the syndicate did not have "any authority over the Ghatwals who are public servants under my control." 52 Together with the protections afforded to the pradhans (village headmen) by the C.N.T. Act, this suggests the presence of several layers of intermediaries that could obstruct, or even outright challenge, the company's control over the land.

The pradhans occupying "waste" or common lands in the villages of Sakchi and Beldih proved to be the single most intractable obstacle for TISCO in its early years. The drastic change in approach toward their claims signaled a shift in the company's exercise of its powers as zamindar. At first, there was a clear recognition of the legal limitations imposed by the original agreement: "The Company cannot eject or oust the Prodhans so long as they pay the stipulated rents and carry out the terms of the Pottah [lease]." There did not appear to be any difficulty in inducing the pradhans to cooperate, if they were "treated with kindness and firmness as it is to their interest to be on friendly terms with the Company."53

But as the steel plant came up and the European population of the town grew to around two hundred, the company began to take a harder line. ${ }^{54}$ TISCO brought a lawsuit against the pradhan of Beldih, on the grounds that he had "unlawfully and without our consent" sub-leased wastelands and erected buildings. The resulting settlement was "a menace to the sanitation of Sakchi and further occupies the only suitable ground upon which the northern town [where European staff lived] may be extended." 55 The pradhan of

50 TSA, Land Acquisition File No. 4 (1908, pt. II), W. O. Renkin to Tata Iron \& Steel Co., 27 Oct. 1908. On the workings of the Chota Nagpur Encumbered Estates Act, which allowed for the temporary seizure and control of insolvent zamindars' property, see D. C. Wadhwa, "Zamindars in Debt," in Dietmar Rothermund and D. C. Wadhwa, eds., Zamindars, Mines and Peasants: Studies in the History of an Indian Coalfield and Its Rural Hinterland (Delhi: Manohar, 1978), 132-33.

51 TSA, Land Acquisition File No. 3 (1908, pt. I), G. McNair to C. M. Weld, 19 Mar. 1908; Dutta, Jamshedpur, 4.

52 TSA, Land Acquisition File No. 3 (1908, pt. I), H. Carey to Messrs. Tata Sons, Bombay, 7 Aug. 1908. The ghatwals (guardians of hill passes and zamindari police) played a crucial role in maintaining colonial authority in Chotanagpur. See Sivaramakrishnan, Modern Forests, 63-64.

53 TSA, Land Acquisition File No. 7 (1911), Morgan \& Co. to Messrs. Tata Sons \& Co., 21 Mar. 1911.

54 TSA, Box 54, File No. A-53, Notes on Substitution of European by Indian Labour, p. 2.

55 TSA, Land Acquisition File No. 8 (1912), Tata Iron \& Steel Co. to the Deputy Commissioner of Singhbhum, 16 Sept. 1912. 
Sakchi, facing a similar lawsuit, argued that the company was not legally entitled to his land "without paying a proper compensation," since he had been "all along in undisturbed possession and enjoyment of the said land and by exercising his permanent right thereon." 56 The company's argument selectively used provisions of the C.N.T. Act against the pradhans, pointing out that all unauthorized sales and transfers of land were prohibited under section 46 of the Act, while "subletting for building purposes" was illegal under section 21. ${ }^{57}$ Not for the first time, the law proved to be a double-edged sword, obstructing as well as enabling the company's claims.

The activities of contractors who settled land on their own and constructed unauthorized buildings offered another visible reminder of the patchwork of multiple sovereignties at Jamshedpur. One contractor in particular, Babu Ramdas, was a thorn in the company's side for many years. In addition to a permanent lease of 50 bighas held directly from the Deputy Commissioner, he secured another 50 bighas on temporary lease for a brickfield. At first, the General Manager was confident that "we can always put pressure on the employees living in Ramdas's quarters to vacate them if necessary," but the Directors' patience ran out. ${ }^{58}$ Word came from Bombay of a sweeping change in policy: "As a general rule, we would prefer that all the areas included in our lease from the Dhalbhum Syndicate, without exception, should be acquired under the Land Acquisition Act," in order to "ensure the perfect safety to our Company for the future." Even after the entire existing leasehold was brought under the company's undisputed control, "we should again hold under lease a belt of land surrounding our whole acquired area." 59 The company's appetite for land was growing, not only due to the wartime boom in profits and the need to expand and modernize the steel plant, but also in direct response to conflicts closer to the ground. The new policy of complete acquisition would allow the pending ejectment suits against the pradhans to be safely dropped, "as the compensation we might have to pay according to the Land Acquisition Officer's estimate will be considerably less than the cost of further litigation." Ramdas's land would be acquired and leased back to him, making his tenants wholly dependent on the company. ${ }^{60}$

56 TSA, Land Acquisition File No. 11 (1917), Tata Iron \& Steel Co. Ltd. vs. Sital Prosad, Title Suit No. 431 of 1917, in the Court of the Musnif at Chaibassa, District Singhbhum, written statement on behalf of the defendant.

57 TSA, Land Acquisition File No. 11 (1917), Opinion of K. Chowdry, Legal Adviser.

58 TSA, Land Acquisition File No. 11 (1917), T. W. Tutwiler to Tata Iron \& Steel Co., Bombay, 28 June 1917. A bigha is a variable measurement of land surface area throughout northern and eastern India, roughly equivalent to half an acre in Bihar.

59 TSA, Land Acquisition File No. 11 (1917), R. D. Tata to The General Manager, Sakchi, 5/6 July 1917 .

60 TSA, Land Acquisition File No. 12 (1918, pt. I), General Manager to Tata Iron \& Steel Co., Bombay, 28 Feb. 1918. 
The resolution of the conflict between TISCO and the numerous intermediaries standing in its way did not exclusively turn on the contradictions of the law. The company's ultimate legal right to eject undesirable occupants of the land was never successfully challenged. Rather, as Matthew Hull has noted in the case of another planned city (Islamabad) where orderly expropriation encountered resistance and subversion, the "clarity and simplicity of the law" was turned into "a site of material struggle" over compensation. ${ }^{61}$ A fully bounded enclave could only come into being once these everyday struggles came to an end. During the second round of negotiations, however, colonial officials appeared to have learned from their mistakes and were determined not to surrender the state's sovereign right over land and mineral resources, whose value was becoming more and more apparent.

\section{DEBATING “PUBLIC PURPOSE”}

TISCO applied for a further 12,000 acres in 1917 for extensions of the plant, employee housing, and leases to subsidiary companies. The price of land had risen from Rs. 13/- per acre to Rs. 133/- per acre and was projected to increase still further. ${ }^{62}$ Partly in order to control costs, the company attempted to secure the right to permanently alienate land and make future acquisitions on its own, without continual recourse to the government. ${ }^{63}$ In response, the Deputy Commissioner of Singhbhum, A. Garrett, penned a long memorandum to the Commissioner of Chota Nagpur, urging the "reconsideration of the whole question of the land acquisition ... at Sakchi as part and parcel of the whole mining field." This question had not been properly addressed because the lands and minerals in this area were "not the property of the State." Garrett was mainly concerned with the costs imposed on the state, both in terms of lost revenue and the problems of law and order posed by a restive mining population. He summarized the status quo as follows: "At Sakchi the situation is a mass of anomalies with a mixture of rural, regular Government, and private police and choukidars in a Municipality that is no Municipality. Everywhere we have given away that real command and control which should be the price of every concession, statutory or otherwise." 64

The "mass of anomalies" Garrett observed was a consequence of the layered and contested sovereignty of the region, where resources could be

${ }^{61}$ Matthew Hull, Government of Paper: The Materiality of Bureaucracy in Urban Pakistan (Berkeley: University of California Press, 2012), 173-74.

62 TSA, Land Acquisition File No. 13 (1918, pt. II), note on Land Acquisition application, 12 Mar. 1918. See also Dutta, Jamshedpur, 15-16; Vishwakarma, Industrialization and Tribal Ecology, 120.

63 TSA, Land Acquisition File No. 12 (1918, pt. I), Draft of the Preliminary Acquisition Agreement, General Manager's Letter no. 306, 19 Jan. 1918.

${ }^{64}$ TSA, Land Acquisition File No. 13 (1918, pt. II), A. Garrett, Deputy Commissioner of Singhbhum to Commissioner of the Chota Nagpur Division, Ranchi, 22 Aug. 1918. 
brought in tax-free from princely to British territory (as was the case with the iron ore shipped from Gurumahisani to Jamshedpur), companies could establish private governments, and the reach of the law was fragmented, incomplete, and twisted by corruption and self-interest. His solution was for the state to "acquire the properties on its own behalf, and give them out on lease to the Companies concerned," which would be "infinitely nearer approximation to the real intention of the legislature and the plain meaning of the [Land Acquisition] Act than the present system." 65

Garrett's memorandum demonstrates the profound contradictions raised by the haphazard application of the Land Acquisition Act to private companies, which undermined the very concept of unitary state sovereignty. Anxieties about whether existing legislation was fit for purpose found echo at both the provincial and imperial levels. The Maude Committee, appointed by the Government of Bihar and Orissa in 1919 to investigate the administration of Jamshedpur, stated in its report that further acquisitions by Tata would be made difficult by the rising price of land and insecurity of tenure in the remaining villages. Colonial officials seriously doubted that the Land Acquisition Act could be used to "clear up problems of doubtful ownership."66 The Committee argued that "the application of the Act has been unduly extended to cover cases in which land is required for private industrial concerns such as the Tata Iron and Steel Company," whose business was now deemed "only indirectly useful to the public." Therefore, unless the Act was amended, the Committee's recommendation was the formation of a statutory Board of Works, a local government authority that would be far better equipped than the company to acquire land in an orderly fashion and assist the dispossessed tenants. ${ }^{67}$

The Maude Committee's report, prompted mainly by the narrow legal question of land acquisition, was the clearest challenge yet to TISCO's de facto sovereignty over Jamshedpur. Ironically, the company itself had precipitated this impasse, by claiming that "we constitute a large Municipality, and as such we are a public body and entitled to the operation of the Land Acquisition Act." ${ }^{68}$ This attempt to assuage the colonial state's doubts about the applicability of the "public purpose" clause soon backfired as land became the main vehicle of a long and unfinished struggle for control over the town.

\section{MUNICIPAL GOVERNANCE AND URBAN PLANNING}

In response to the Maude Committee's report, TISCO agreed that a Board of Works should be constituted to perform "administrative functions," but

65 Ibid.

66 NAI, Commerce \& Industries (Industries Branch), A Proceedings, nos. 1-9 (Mar. 1919), note by A. E. Gilliat in the Revenue \& Agriculture Department, 19 Sept. 1918.

67 India Office Records, British Library, London (hereafter IOR), Mss Eur E251/22, Papers of Sir Maurice Hallett, Report of the Jamshedpur Committee, p. 22.

${ }^{68}$ TSA, Land Acquisition File No. 12 (1918, pt. I), Memorandum, 11 June 1918. 
without the power to alienate property. ${ }^{69}$ In 1924, when Jamshedpur was declared a municipality under section 388 of the Bihar and Orissa Municipal Act of 1922, the Board of Works was converted into a Notified Area Committee. TISCO refused to recognize this body as an independent municipal authority, which meant that no public property technically existed in Jamshedpur. Elsewhere in colonial India, notably in the Punjab, the declaration of a notified area was not necessarily a step toward full municipal status. Indeed, many localities materially resembling cities were deliberately listed as notified areas or even villages, mainly for reasons of taxation. ${ }^{70}$ The company took advantage of this ambiguity to argue for the indefinite continuation of the status quo.

Concerns over infrastructure provision, however, soon provoked an impasse. Chief Town Engineer F. C. Temple, formerly the Sanitary Engineer for the Government of Bihar and Orissa, authored the first urban plan for Jamshedpur in 1919. The plan laid out an integrated road system based on the old village cart tracks in a system of "loops" and "ring roads."71 The company had initially refused to assume the responsibility to "maintain any roads much less make them, because there are no such things as roads in the place but only cart or jungle tracks." Whatever roads they did build were kept open at the company's discretion, while villagers' claims to rights-of-way were summarily dismissed. ${ }^{72}$ Temple urged the Directors to reconsider their stance for reasons of self-interest. "Assuming that Govt. declares the roads public, \& that is almost a certainty if we do not," he explained, " $\&$ assuming that Govt. resumes comparatively large areas of land for residential purposes ... we should run the very serious risk that the next NAC would no longer have a Steel Co. majority.",73 The Directors were inclined to agree with Temple, recognizing that the situation was untenable: "The public cannot obtain admission to the Courts at Jamshedpur or the Government Hospital or the Police Stations or even the Jail without using roads we have expressly declared to be private roads and which we close once a year.",74

A slow devolution of municipal government to an elected body would also bring a measure of financial relief to the cash-strapped company, which had

69 TCA, T53-DES-T34-MINUTES-3-020-21, TISCO Board Meeting held on 4 Nov. 1919.

70 William J. Glover, "The Small Town in Colonial Punjab," unpublished paper cited with kind permission of the author.

71 F. C. Temple, Report on Town Planning, Jamshedpur Social Welfare Series (Bombay: Commercial Press, 1919), 5-11; Sinha and Singh, "Planning an Ideal Steel City in India," 268-70.

72 TSA, Land Acquisition File No. 4 (1908, pt. II), G. B. McNair to B. J. Padshah, 4 Sept. 1908; Land Acquisition File No. 5 (1908, pt. III), W. O. Renkin to The Tata Iron \& Steel Co., 31 Aug. 1908.

73 IOR, Mss Eur D296/2, F. C. Temple to John Peterson, 19 Oct. 1925.

74 IOR, Mss Eur D296/2, Municipal Administration at Jamshedpur, note by John Peterson, proposals sanctioned by Board of Directors, 24 Nov. 1925. 
requested government assistance for the town's upkeep. ${ }^{75}$ As the postwar economic boom came to a crashing end, the TISCO Board of Directors in Bombay began to contemplate giving up control over Jamshedpur, a position unthinkable a few years earlier. ${ }^{76}$ The seeds of compromise between the company and the state were sown by subordinating the principle of unitary sovereignty to the practical task of providing law and order. As the Deputy Commissioner of Singhbhum put it in 1927:

It is clearly undesirable that a private company, almost uncontrolled by Government, should be the one and only authority in a large modern town. It is particularly wrong that a company supplying essential public services, like water, power and light, should not be subject to the law which ordinarily controls such services, and be able to enforce their will and get rid of undesirable persons by refusing supplies. On the other hand a democratic form of Government would be dangerous in Jamshedpur, and the Company must always have a large voice in the administration of the town. ${ }^{77}$

Dain's position on the question of Jamshedpur's municipal status thus inverted his predecessor Garrett's argument, made a decade before. If the role of state as supreme landlord and rentier was derived from the exercise of police power, the realities of administering a company town made private governance an acceptable substitute.

TISCO secured its position as zamindar and municipal authority under a particular set of legal and financial constraints. From 1929 to 1939, the growth of Jamshedpur was limited to the area between the rivers Kharkhai and Subarnarekha. The need for further acquisitions continued to plague town administrators, as the Maude Committee had predicted. In order to detect and prevent the spread of "slum areas," the Board of Directors commissioned an aerial survey, a common instrument of governmentality across the British Empire in this period. The view from the air tended to reveal "a reality that demanded improvement and development," in this case confirming the fundamental defects of Jamshedpur's growth. ${ }^{78}$ A second urban plan by Army engineer P.G.W. Stokes, completed in 1937, recommended acquiring a further belt of land within a 2-3 mile radius to control land speculation. "Had the original planner of Jamshedpur been gifted with omniscience," Stokes wrote, "he would have planned it in concentric rings, with the lowest class dwellings nearest the

75 IOR, Mss Eur D296/2, note by M. G. Hallett, Commissioner, 6 Nov. 1927.

76 TCA, T30-DES-History Project-1, John Peterson to S. Sinha, Member, Executive Council, Govt. of Bihar \& Orissa, 2 Jan. 1924. Peterson's rather desperate proposal relied on the same logic employed by colonial officials aiming to wrest control of Jamshedpur from TISCO. "A private town of this size owned by a private corporation," he conceded, "is a thing unknown in any other country in the world and we should be very glad indeed to be relieved of the responsibility of it."

77 IOR, Mss Eur D296/2, Deputy Commissioner, Singhbhum, to F. C. Temple, 18 Oct. 1927.

78 TCA, T53-DES-T34-MINUTES-11-004, TISCO Board Meeting No. 1177 held on January 25, 1936; Peter Adey, Aerial Life: Spaces, Mobilities, Affects (Oxford: Wiley-Blackwell, 2010), 87. 
works, and the highest class furthest." ${ }^{, 79}$ Instead, the residential neighborhoods for skilled workers and middle management, known as the Northern Town, were located next to the factory due to the exigencies of the land acquisition process (which, as we have seen, involved skirting already populated villages). The appearance of overcrowded slums (bastis) within the acquired area and the "unsanitary" development of the village of Jugsalai just outside its boundaries, where an independent pradhan encouraged speculation amidst rising land values, exacerbated the problem. ${ }^{80}$

Jugsalai stood in stark contrast with the sedate suburban utopia of Jamshedpur's Northern Town only a few miles away. One TISCO employee later recalled that Jugsalai was surrounded by wild jungle, and "people did not dare to walk alone ... for fear of dacoits and ferocious animals even in day time." ${ }^{81}$ The company had long considered "the possibility of doing something" about the village, but made no progress since it would "cost a good deal of money." 82 When the government proposed extending the Great Eastern Road from Chaibasa to Calcutta, which would have entailed constructing a bridge over the Subarnarekha and connecting the north bank with Jamshedpur, the Deputy Commissioner suggested "that we should consider the advisability of taking steps to prevent the growth on the north side of the proposed bridge of an area which might develop the unsatisfactory features of Jugsalai." The company called for the application of the Land Acquisition Act, accepting restrictions on the use of the land "for industrial development or as a substantial source of profit." ${ }^{\prime 83}$ Jugsalai was Jamshedpur's antithesis, a shadow space produced by the very model urbanism it now threatened through the mystifying (and seemingly uncontrollable) rise in land prices.

Within the acquired area, by contrast, the newly constituted Town Department became "a great productive asset" to the company, implementing the first systematic survey of land valuation and seeking to enhance the income derived from rents. When the TISCO Board of Directors examined the two principal components of the Town Revenue Budget, it found that municipal services were in constant deficit, but land and house rents showed a healthy profit. ${ }^{84}$ It had been "impossible to increase these rents although we are trying to do

79 TSA, Box 779, “Jamshedpur Town Planning Scheme” by P.G.W. Stokes (1937), p. 5; Sinha and Singh, "Planning an Ideal Steel City in India," 270.

${ }^{80}$ Dutta, Jamshedpur, 32-36; Vishwakarma, Industrialization and Tribal Ecology, 131. For Tata Steel today, Jugsalai remains a source of subversion due to the presence of a free press. Interview with R. S. Agrawal, editor of Uditvani, a Hindi-language daily newspaper based in Jugsalai, Apr. 2014.

${ }^{81}$ TSA, Box 698, “What I Have Seen in Jamshedpur," by S. Modak (1969), p. 2.

82 TSA, General Manager's Correspondence File No. $169(135$, pt. I), note on Road Bridge over the Subarnarekha, 9 Jan. 1935.

${ }^{83}$ TSA, General Manager's Correspondence File No. 169 (1935, pt. I), J.R.D. Tata to General Manager, 10 Jan. 1935.

${ }^{84}$ TCA, T53-DES-T34-MINUTES-09, TISCO Board Meeting held on 20 April 1934. 
so gradually." 85 This was not a new problem. When the colonial government acquired lands in the Punjab for the construction of New Delhi a decade earlier, it compensated for lost agricultural revenue by allowing tenants to remain on the land upon payment of rent. ${ }^{86}$ As the state increasingly followed the logic of the market, the company behaved more and more like a state.

To maintain its overall profitability, the Town Department began to sue for arrears of rent in its capacity as zamindar under section 234 of the C.N.T. Act. ${ }^{87}$ The company's suits imposed a crushing burden on the tenants that soon found expression in organized political action. A speech delivered before the Singhbhum District Kisan Conference in 1939, recorded in peasant leader Swami Sahajanand's memoirs, described the "horrible sufferings (bhayankar kashton)" of the villagers within the acquired area, including an increase in rent (up to four times higher than in nearby districts). The villagers complained that, "We enjoy no benefits of any kind from this municipality," whose services were intended exclusively for TISCO staff and its permanent workforce. ${ }^{88}$

The precise legal status of Jamshedpur's residents became a point of contention once again in 1937, when the Chota Nagpur Tenancy Act (Amendment) Bill sought to "amend clause 78 of the 1908 Act by affording protection to "Raiyats" owning homesteads from ejectment on account of arrears of rent accruing on such homesteads only." This amendment would, the General Manager submitted to the Bihar Government, "vitally affect the administration of acquired areas in Jamshedpur" by interfering with the company's right to terminate leases. Although acknowledging, in passing, the continued existence of prior agricultural tenants whose rights were protected, the General Manager argued, "The greater portion of the agricultural lands in Jamshedpur are held by persons who are not raiyats in the popular interpretation of the word" but persons employed by the company who had been given small plots of land for vegetable gardens. Any land "held for residential or business purposes has to be subject to regulations and bylaws of a municipal nature," which would be undermined if these tenants were to claim the status of agriculturists. ${ }^{89}$ The C.N.T. Act continued to serve as a destabilizing force challenging the company's undisputed control over the land, which required the reinvention and redeployment of categories such as raiyat or urban resident. This was one

85 TSA, Land Acquisition File No. 22 (1929), note placed before the Board of Directors on 7 Aug. 1929.

${ }^{86}$ David A. Johnson, "Land Acquisition, Landlessness, and the Building of New Delhi," Radical History Review 108 (Fall 2010): 91-116.

${ }^{87}$ TSA, Land Acquisition File No. 10 (1915), note by K. Chowdry, Legal Adviser, 1 Nov. 1915.

${ }^{88}$ Walter Hauser, ed., Swami Sahajanand and the Peasants of Jharkhand: A View from 1941 (Delhi: Manohar, 1995), 189-91.

89 TSA, General Manager's Correspondence File No. 172 (1938, pt. I), J. J. Ghandy, General Manager, to Sri Krishna Sinha, Prime Minister for Home Affairs, Patna, 15 Feb. 1938. 
of many strategies available to the company for working through and around the law.

\section{CONCLUSION}

In histories of postcolonial urbanism in South Asia and beyond, Jamshedpur is often relegated to the status of a footnote, seen as no more than an isolated experiment by colonial-era capitalists laying the groundwork for the advent of the "new town" movement under the aegis of the state during the 1950s. ${ }^{90}$ But its anomalous legal status and fraught relationship with the surrounding region deeply unsettled urban planners' aspirations for integrated economic and social development. The German-Jewish émigré Otto Koenigsberger produced the ambitious Jamshedpur Development Plan in 1945 for TISCO-the third and most comprehensive attempt yet to fix the town's problems (after Temple's and Stokes' earlier efforts). He, too, failed to stop the growth of Jugsalai and other squatter settlements. Koenigsberger recognized that Jamshedpur had essentially become a fortified enclave, "troubled by movements that originate outside its boundaries but impinge on the life of its people." It simply lacked the necessary administrative powers (of taxation, policing, and eminent domain) to plan for growth on a holistic regional basis. ${ }^{91}$ This was a largely political consequence of Jamshedpur's evolution as a privately governed company town that no planner or expert alone could redress.

The American Albert Mayer, who headed the Ford Foundation team working on the Master Plan for the Delhi Development Authority, also confronted the Jamshedpur precedent when tasked with drawing up a scheme for "industrial estates" under the Second Five-Year Plan. Unsure of the "relative advantages and disadvantages" of locating these estates "in a small city as compared with a metropolis," he collected varying opinions from experts. ${ }^{92}$ On the one hand, anthropologist Evelyn Wood assured Mayer that "the steel town of Jamshedpur has had a profound effect on the people of the countryside," encouraging "useful changes in local farming, which was very primitive.",93 On the other, economist J. B. Condliffe warned that industrial enterprises located in "backward areas" might "develop, as Jamshedpur has done over half a century with little or no effect on the surrounding countryside." The result would be a neocolonial "dual economy," or "modern mines, factories and plantations using mechanized equipment in the midst of inefficient

90 Roy, Beyond Belief, 137-38; Wakeman, Practicing Utopia, 120.

91 Architectural Association, London, Otto Koenigsberger Papers, box 31, "The Implementation of the Jamshedpur Development Plan of 1942/44," note submitted by Koenigsberger to R. S. Pande, Resident Director, TISCO, 5 Apr. 1967.

92 Albert Mayer Papers, University of Chicago, Mayer to Bata Shoe Co., Faridabad, 17 Feb. 1959.

93 Albert Mayer Papers, Evelyn Wood to Mayer, 28 June 1958. 
traditional techniques."94 The prospect of "parasitic" industrial towns impoverishing rather than uplifting rural areas would not disappear with the imposition of unified state sovereignty. ${ }^{95}$

In the democratizing milieu of the Nehruvian period, Jamshedpur's anomalous legal status did come under growing scrutiny. The Bihar Land Reforms Act of 1950 triggered a thirty-year court battle leading to a renegotiation of lease terms. According to the provisions of an agreement signed between TISCO (subsequently renamed Tata Steel) and the state of Bihar in 1984, the entirety of the acquired area was retroactively vested in the government. The company would thenceforth hold it on a renewable lease, subject to an obligation "to maintain the standard of Municipal Services and Civic amenities being rendered by them in Jamshedpur." 96 The latter clause would provide the legal basis for the demand to finally declare Jamshedpur a municipality. Local activist Jawaharlal Sharma filed and won a public interest litigation (PIL) in the Supreme Court in 1988, arguing that the Indian Constitution guaranteed a "third vote" (for local government) to every citizen and pointing to the irregular distribution of municipal services as evidence of harm. However, the Supreme Court's order was never implemented, and the residents of Jamshedpur rose up in protest against the surrender of their township to what many perceived as a corrupt and lawless Bihar government. This may have been due to the widespread "psychological comfort and security of being taken care of" by the company, or what Mr. Sharma, still fighting his case as of 2014, refers to as a state of ghulami (slavery). ${ }^{97}$

94 Albert Mayer Papers, J. B. Condliffe to Tarlok Singh, 12 June 1960.

95 Roy, Beyond Belief, 144. In Brasília, the crown jewel of midcentury modernist urbanism, the Company to Urbanize the New Capital of Brazil (NOVACAP) originally attempted to create a ring of agricultural cooperatives around the city in order to ameliorate the rural-urban divide. Instead, an "illegal periphery" of squatter settlements, comparable to Jugsalai, quickly evolved. The state responded by "authorizing" or regularizing these "satellite cities," which TISCO as a private company could (or would) not do. See James Holston, The Modernist City: An Anthropological Critique of Brasília (Chicago: University of Chicago Press, 1989), 257-58. Reflecting on the experience of a wide variety of planned industrial towns in South America, particularly Ciudad Guayana in Venezuela, Felipe Correa concludes, "The incorporation of extralegal areas into the legal realm of the city, followed by a plan of physical upgrades, is one of the most effective ways to restore slums." Beyond the City: Resource Extraction Urbanism in South America (Austin: University of Texas Press, 2016), 108.

96 Agreement for Lease between Govt. of Bihar and Tata Iron and Steel Company (TISCO), 4 Aug. 1984. The latest agreement was signed in 2005 with the newly formed Jharkhand government. It contained a controversial provision to exclude the bastis from the leasehold, thus depriving these areas of municipal services. Interview with Saryu Roy, former BJP Member of the Legislative Assembly, Jamshedpur, Apr. 2014. Roy is also an environmental and social activist who led the jal satyagraha calling for the provision of drinking water connections to the bastis in January 2013. He has made available the full texts of the various agreements between Tata Steel and the Governments of Bihar and Jharkhand on his personal website: <http:/www.saryuroy.in/intvs/> (accessed 16 Aug. 2016).

97 Interview with Jawaharlal Sharma, Jamshedpur, Apr. 2014; Kling, "Paternalism in Indian Labor," 83-84; Barbara Crossette, "Good Government Scares a Good City in India," New York 
Jamshedpur, today an urban agglomeration of more than one million people, has not been officially declared a municipality. Utilities and services continue to be provided for by Tata Steel, through a nominally independent subsidiary. However, the company has gradually moved away from a "Jamshedpur-centric model" since the opening of a new steel plant in Kalinganagar, Odisha, in 2015. Senior management concedes that integrated townships with full provision of municipal services are unlikely to be replicated at future sites. ${ }^{98}$ Some activists and critics even believe that Jamshedpur will cease to be a productive industrial space within the next twenty years, and will be useful to Tata Steel strictly for speculation in the land itself - a fear tempered by the hope that the company will finally surrender control. ${ }^{99}$

Jamshedpur's resilience as a privately governed space of extraction and production for over a century speaks to ongoing debates about law and capitalism in a globalized world. The proliferation of special economic zones (SEZs) and other sites where the regulatory reach of the state is limited suggests that "the control over territory and bodies that marked the nation-state model of sovereignty is now supplemented by a powerful drive to control the 'legal contract' - the modern-day concession that empowers private companies to carry out state functions."100 The legal apparatus underpinning land grabs in the present is often understood in terms of a return to a deeper past. In the case of postcolonial sub-Saharan Africa, James Ferguson has drawn a sharp distinction between "socially 'thick" mining industries on the Zambian Copperbelt in the first half of the twentieth century, which provided housing and services to workers in company towns, and a more recent "socially "thin"" oil economy based on enclaves "sharply walled off from their own national societies." This new spatial arrangement resembles "colonial-era extraction" by "private companies with private armies," such as King Leopold's infamous rubber concession companies in the Congo and Cecil Rhodes's British South Africa Company. ${ }^{101}$ By contrast, Dinah Rajak has argued that mining in southern Africa has always been "deeply territorial, as is the kind of social authority which many mining companies continue to exert in the localities where they operate.",102

Times, 22 Jan. 1991; Divya Gupta, "Moral Minefield," Caravan, 1 Nov. 2011, <http://www.caravan magazine.in/reporting-and-essays/moral-minefield $>$ (accessed 16 Aug. 2016).

98 Interviews with former Managing Director and former Vice-President of Town, Medical and Social Services, Tata Steel, Bombay, Feb. 2014.

99 Interviews with Xavier Dias, Ranchi, Apr. 2014; R. S. Agrawal, Jugsalai, Apr. 2014.

100 Thomas Blom Hansen and Finn Stepputat, "Sovereignty Revisited," Annual Review of Anthropology 35 (2006): 295-315.

101 James Ferguson, Global Shadows: Africa in the Neoliberal World Order (Durham: Duke University Press), 36-38, 207.

102 Dinah Rajak, In Good Company: An Anatomy of Corporate Social Responsibility (Stanford: Stanford University Press, 2011), 19. 
Jamshedpur disturbs both the "thick"/“thin" distinction and the notion of a consistent territoriality by showing how corporate sovereignty is enacted through protracted legal struggles that fix its spatial boundaries. Here a pure enclave could not be realized due to the many compromises necessary to secure control over the land, which created openings for recurring challenges to the steel company's authority as zamindar and magistrate. Conversely, the reproduction of legal anomalies and exceptions prevented Jamshedpur from becoming more closely integrated into the surrounding regional economy, more fully subject to the state, and more responsive to democratic claims making from below.

\begin{abstract}
This article examines the emergence of Jamshedpur, site of India's first steel plant and privately governed company town, as part of an unprecedented large-scale extraction of mineral resources at the turn of the twentieth century for the purpose of industrial development. It traces the protracted acquisition of land and dispossession of mainly adivasi (tribal) cultivators by the Tata Iron and Steel Company (TISCO) from ca. 1900 to 1930. The company pursued a distinct strategy of obtaining short-term leases from princely states and zamindars (landowners), while simultaneously appealing to the legal apparatus of the colonial state to secure absolute tenurial rights. The uneven application of laws such as the Land Acquisition Act (1894) and the Chota Nagpur Tenancy Act (1908) allowed TISCO to become a quasi-sovereign power in eastern India, simultaneously acting as employer, landlord, and municipal government. Jamshedpur's continually anomalous legal status underlies the persistence of multiple, fragmented, and competing sovereignties in India, even as an ostensibly unified national economic state space emerged by the time of independence in 1947. More broadly, it suggests that the contours of the relationship between states and corporations, particularly in a postcolonial context, are determined both by preexisting political geographies and contingent legal struggles.
\end{abstract}

Key words: colonialism, corporations, company towns, India, industrialization, Jamshedpur, land acquisition, sovereignty, Tata, urban planning, zamindars 